УДК $631.8+631.559$

DOI 10.36461/NP.2020.54.1.010

\title{
ПОСЛЕДЕЙСТВИЕ ОСАДКОВ СТОЧНЫХ ВОД Г. ПЕНЗЫ И ПРИРОДНОГО ЦЕОЛИТА НА УРОЖАЙНОСТЬ И КАЧЕСТВО РАСТЕНИЕВОДЧЕСКОЙ ПРОДУКЦИИ
}

\author{
А. Н. Арефьев, доктор с.-х. наук, доцент; Е. Н. Кузин, доктор с.-х. наук, профрессор; \\ Г. В. Ильина, доктор биол. наук, профессор \\ Федеральное государственное бюджетное образовательное учреждение \\ высшего образования «Пензенский государственный аграрный университет», Россия, \\ т. (8412) 62-83-67, e-mail: aan241075@yandex.ru
}

\begin{abstract}
В условиях низкого уровня использования минеральных удобрений в земледелии в связи с высокой их стоимостью и почти полного отсутствия органических удобрений разработка и внедрение в земледельческую практику технологических приемов использования альтернативных источников органического вещества и элементов питания является актуальным направлением современного земледелия. Задача исследований заключалась в изучении последействия мелиоративных норм осадков сточных вод г. Пенза и их сочетаний с цеолитсодержащей породой на урожайность и качество растениеводческой продукции. Исследования проводились в первом агропочвенном районе Пензенской области в зернопаропропашном севообороте в период с 2014 по 2019 гг. Установлено, что наиболее существенное влияние на урожайность зерна овса и гороха оказали повышенные нормы осадков городских сточных вод с цеолитсодержащей породой. Урожайность овса на их фоне возрастала на 43,5-44,2 \%, урожайность гороха на 48,9-49,8 \%. Сбор переваримого протеина в посевах овса на их фоне составлял 487,9-490,3 кг/га, содержание белка в зерне гороха увеличивалось на 2,3-2,7 \%. Осадки городских сточных вод в чистом виде и в комплексе с цеолитсодержащей породой повышали концентрацию тяжелых металлов в зерне овса и гороха. Однако, концентрация тяжелых металлов была существенно ниже ПДК. Цеолитсодержащая порода снижала поступление тяжелых металлов в товарную часть растениеводческой продукции.
\end{abstract}

Ключевые слова: осадки городских сточных вод, цеолитсодержащая порода, овес, горох, переваримый протеин, белок.

\section{Введение}

Одним из существенных факторов, влияющих на продуктивность сельскохозяйственных культур и качество растениеводческой продукции, является использование органических удобрений, способствующих обогащению ее органическим веществом и элементами питания растений [1-3].

Разработка и внедрение в земледельческую практику агробиологических приемов повышения эффективного плодородия и продуктивности сельскохозяйственных культур с высоким качеством растениеводческой продукции на основе использования боле дешевых местных сырьевых ресурсов (осадки городских сточных вод (ОГСВ), цеолитсодержащие руды, диатомит и т. д.) является актуальным направлением современной аграрной науки [4-9].

Одним из лимитирующих факторов использования осадков городских сточных вод в качестве органо-минеральных удобрений является содержание в них тяжелых металлов. При выращивании сельскохозяйственных культур на фоне использова- ния осадков сточных вод в растения из почвы неизбежно поступают тяжелые металлы, которые могут накапливаться в товарной части урожая и представлять угрозу для здоровья человека и животных. Контроль за содержанием тяжелых металлов в почве и в товарной продукции растениеводства приобретает, в связи с этим особое значение [10-15].

\section{Методы и материалы}

Исследования по изучению последействия мелиоративных норм осадков сточных вод г. Пенза и их сочетаний с цеолитсодержащей породой Лунинского месторождения на урожайность и качество растениеводческой продукции проводились на лугово-черноземной выщелоченной малогумусной среднемощной среднесуглинистой почве в 2018-2019 гг. Для решения поставленных задач в 2014 году был заложен полевой опыт по схеме: 1. Без ОГСВ и клиноптилолита (контроль); 2. Клиноптилолит 10 т/га; 3. ОГСВ 100 т/га + клиноптилолит 10 т/га; 4. ОГСВ 120 т/га + клиноптилолит 10 т/га; 5. ОГСВ 140 т/га + клиноптило- 
Урожайность овса (2018 е.)

\begin{tabular}{|l|c|c|c|}
\hline \multicolumn{1}{|c|}{ Вариант } & Урожайность, & \multicolumn{2}{c|}{ Отклонение от контроля } \\
\cline { 3 - 4 } & т/га & т/га & $\%$ \\
\hline 1. Без ОГСВ и клиноптилолита (контроль) & 2,76 & - & - \\
\hline 2. Клиноптилолит 10 т/га & 3,15 & 0,39 & 14,1 \\
\hline 3. ОГСВ 100 т/га & 3,12 & 0,36 & 13,0 \\
\hline 4. ОГСВ 120 т/га & 3,30 & 0,54 & 19,6 \\
\hline 5. ОГСВ 140 т/га & 3,37 & 0,61 & 22,1 \\
\hline 6. ОГСВ 160 т/га & 3,51 & 0,75 & 27,2 \\
\hline 7. ОГСВ 180 т/га & 3,51 & 0,75 & 27,2 \\
\hline 8. ОГСВ 100 т/га + клиноптилолит 10 т/га & 3,52 & 0,76 & 27,5 \\
\hline 9. ОГСВ 120 т/га + клиноптилолит 10 т/га & 3,68 & 0,92 & 33,3 \\
\hline 10. ОГСВ 140 т/га + клиноптилолит 10 т/га & 3,83 & 1,07 & 38,8 \\
\hline 11. ОГСВ 160 т/га + клиноптилолит 10 т/га & 3,96 & 1,20 & 43,5 \\
\hline 12. ОГСВ 180 т/га + клиноптилолит 10 т/га & 3,98 & 1,22 & 44,2 \\
\hline НСР & & 0,14 & \\
\hline
\end{tabular}

лит 10 т/га; 6. ОГСВ 160 т/га + клиноптилолит 10 т/га; 7. ОГСВ 180 т/га + клиноптилолит 10 т/га.

Повторность опыта трехкратная, варианты в опыте размещены методом рендомизированных повторений, учетная площадь одной делянки $4 \mathrm{~m}^{2}$. В опыте использовались осадки сточных вод г. Пенза. Содержание тяжелых металлов в осадках сточных вод характеризовалось следующими данными в мг/кг сухого вещества в осадках: цинк - 389,73, медь - 168,42, свинец - 46,14, никель - 89,45, кадмий $-6,98$, марганец - 174,36. Содержание подвижных форм тяжелых металлов в почве перед закладкой опыта составляло в мг/кг почвы: цинк $-5,28$, медь $-0,18$, свинец - 0,98, никель $-0,84$, кадмий $-0,09$. Концентрация тяжелых металлов в сухом веществе осадков сточных вод г. Пенза и в луговочерноземной почве была значительно ниже предельно-допустимой концентрации. В опыте в качестве химического мелиоранта применялась цеолитсодержащая агроруда
Лунинского месторождения. Норма химического мелиоранта рассчитывалась по содержанию клиноптилолита в цеолитсодержащей породе. Содержание клиноптилолита в цеолитсодержащей породе составляло $41 \%$. Исследования были проведены в зернопаропропашном севообороте. В 2018 году в опыте возделывался овес Конкур, в 2019 году - горох Джекпот.

\section{Результаты}

Урожайность овса в условиях 2018 года на контрольном варианте составляла 2,76 т/га. Цеолитсодержащая порода, при ее одностороннем последействии, повышала урожайность овса на 0,39 т/га, или $14,1 \%$ (табл. 1).

Урожайность овса на фоне последействия осадков городских сточных вод, в зависимости от их нормы, изменялась в пределах от 3,12 до 3,51 т/га, превышая контроль на 0,36 (ОГСВ 100 т/га) - 0,75 т/га (ОГСВ 180 т/га), или на 13,0-27,2 \%.

Комплексное последействие осадков городских сточных вод с цеолитсодержащей

Таблица 2

Сбор переваримого протеина

\begin{tabular}{|l|c|c|c|}
\hline \multicolumn{1}{|c|}{ Вариант } & Сбор переваримого & Отклонение от контроля \\
\cline { 3 - 4 } & протеина, кг/га & кг/га & $\%$ \\
\hline 1. Без ОГСВ и клиноптилолита (контроль) & 306,9 & - & - \\
\hline 2. Клиноптилолит 10 т/га & 366,4 & 59,5 & 19,4 \\
\hline 3. ОГСВ 100 т/га & 359,1 & 52,2 & 17,0 \\
\hline 4. ОГСВ 120 т/га & 384,1 & 77,2 & 25,2 \\
\hline 5. ОГСВ 140 т/га & 397,3 & 90,4 & 29,5 \\
\hline 6. ОГСВ 160 т/га & 417,7 & 110,8 & 36,1 \\
\hline 7. ОГСВ 180 т/га & 418,0 & 111,1 & 36,2 \\
\hline 8. ОГСВ 100 т/га + клиноптилолит 10 т/га & 421,0 & 114,1 & 37,2 \\
\hline 9. ОГСВ 120 т/га + клиноптилолит 10 т/га & 444,9 & 138,0 & 45,0 \\
\hline 10. ОГСВ 140 т/га + клиноптилолит 10 т/га & 467,6 & 160,7 & 52,4 \\
\hline 11. ОГСВ 160 т/га + клиноптилолит 10 т/га & 487,9 & 181,0 & 59,0 \\
\hline 12. ОГСВ 180 т/га + клиноптилолит 10 т/га & 490,3 & 183,4 & 59,8 \\
\hline НСР & & 16,4 & \\
\hline
\end{tabular}


Последействие ОГСВ и цеолита на урожай гороха (2019 г.)

\begin{tabular}{|c|c|c|c|c|c|}
\hline \multirow[t]{2}{*}{ Вариант } & \multirow[t]{2}{*}{$\begin{array}{l}\text { Урожай- } \\
\text { ность, }\end{array}$} & \multicolumn{2}{|c|}{$\begin{array}{l}\text { Отклонение } \\
\text { от контроля }\end{array}$} & \multirow[t]{2}{*}{$\begin{array}{c}\text { Содержание } \\
\text { белка в }\end{array}$} & \multirow[t]{2}{*}{$\begin{array}{l}\text { Отклонение } \\
\text { от контро- }\end{array}$} \\
\hline & & т/га & $\%$ & & \\
\hline 1. Без ОГСВ и клиноптилолита (контроль) & 2,29 & - & - & 20,5 & - \\
\hline 2. Клиноптилолит 10 т/га & 2,67 & 0,38 & 16,6 & 20,8 & 0,3 \\
\hline 3. ОГСВ 100 т/га & 2,69 & 0,40 & 17,5 & 21,4 & 0,9 \\
\hline 4. ОГСВ 120 т/га & 2,71 & 0,42 & 18,3 & 21,7 & 1,2 \\
\hline 5. ОГСВ $140 \mathrm{~T} / \mathrm{гa}$ & 2,85 & 0,56 & 24,5 & 22,0 & 1,5 \\
\hline 6. ОГСВ 160 т/га & 3,08 & 0,79 & 34,5 & 22,5 & 2,0 \\
\hline 7. ОГСВ 180 т/га & 3,09 & 0,80 & 34,9 & 22,8 & 2,3 \\
\hline 8. ОГСВ 100 т/га + клиноптилолит 10 т/га & 2,90 & 0,61 & 26,6 & 21,7 & 1,2 \\
\hline 9. ОГСВ 120 т/га + клиноптилолит 10 т/га & 3,08 & 0,79 & 34,5 & 21,1 & 1,6 \\
\hline 10. ОГСВ 140 т/га + клиноптилолит 10 т/га & 3,10 & 0,81 & 35,4 & 22,4 & 1,9 \\
\hline 11. ОГСВ 160 т/га + клиноптилолит 10 т/га & 3,41 & 1,12 & 48,9 & 22,9 & 2,3 \\
\hline 12. ОГСВ 180 т/га + клиноптилолит 10 т/га & 3,43 & 1,14 & 49,8 & 23,2 & 2,7 \\
\hline $\mathrm{HCP}_{05}$ & & 0,18 & & & 1,1 \\
\hline
\end{tabular}

породой повышало урожайность овса на 0,76-1,22 т/га, или на 27,5-44,2\%.

Установлено, что одностороннее последействие осадков городских сточных вод нормами 160 и 180 т/га и их комплексное последействие с цеолитсодержащей породой оказали практически одинаковое влияние на урожайность овса. Урожайность зерна овса в первом случае составляла 3,51 т/га, а во втором - 3,96-3,98 т/га.

Как показали исследования, последействие цеолитсодержащей породы повышало сбор переваримого протеина на 59,5 кг/га, или 19,4\%. При одностороннем последействии осадков городских сточных вод сбор переваримого протеина, в зависимости от нормы осадка, увеличивался по отношению к контролю на 52,2-111,1 кг/га, или на 17,0-36,2 \% (табл. 2).

Максимальный сбор переваримого протеина был отмечен на фоне последействия осадков городских сточных вод с цеолитсодержащей породой. Сбор переваримого протеина от их совместного последействия превышал контроль на 114,1183,4 кг/га, или 37,2-59,8 \%.

Урожайность зерна гороха на фоне одностороннего последействия цеолитсодержащей породы достоверно превышала контроль на 0,38 т/га, или 16,6 \% и составляла 2,67 т/га (табл. 3).

Последействие осадков городских сточных вод, в зависимости от их нормы, достоверно увеличивало урожайность гороха на 0,40-0,80 т/га, или на 17,5-34,9\%. На фоне комплексного последействия осадков городских сточных вод с цеолитсодержащей породой урожайность гороха возрастала по отношению к контролю на 0,61-1,14 т/га, или на 26,6-49,8 \%. Максимальная урожайность была получена на фоне по- следействия осадков городских сточных вод нормами 160 и 180 т/га в комплексе с цеолитсодержащей породой.

Содержание белка в зерне гороха составляло 20,5\%. Последействие цеолитсодержащей породы и осадков сточных вод нормой 100 т/га не обеспечивали достоверного увеличения содержания белка в зерне гороха (табл. 3).

На фоне последействия осадков городских сточных вод нормами от 120 до 180 т/га содержание белка в зерне гороха варьировало в пределах от 21,7 до 22,8 \%, достоверно превышая контроль на 1,2$2,3 \%$. На вариантах с последействием осадков городских сточных вод в комплекce с цеолитсодержащей породой содержание белка в зерне гороха изменялось в интервале от 21,7 до 23,2 \%. Увеличение по отношению к контролю было достоверным и составляло 1,2-2,7 \%.

Результаты исследований показали, что в зерне овса в 2018 году на варианте без использования осадков городских сточных вод и цеолитсодержащей породы содержание тяжелых металлов было ниже предельно допустимой концентрации в 3,6-10,0 раз. Последействие цеолитсодержащей породы снижало содержание цинка в зерне овса на 3,9 мг/кг, меди - на 0,21 мг/кг, свинца - на 0,027 мг/кг, никеля - на 0,010 мг/кг, кадмия на 0,002 мг/кг (табл. 4).

На фоне одностороннего последействия осадков городских сточных вод содержание цинка в зерне овса, в зависимости от нормы осадка, варьировало в интервале от 18,9 до 32,3 мг/кг, меди от 1,61 до 2,90 мг/кг, свинца от 0,097 до 0,177 мг/кг, никеля от 0,060 до 0,119 мг/кг, кадмия от 0,010 до 0,018 мг/кг, содержание тяжелых металлов было ниже предельно допустимой концентрации. 
Содержание тяжелых металлов в зерне овса, мг/кट

\begin{tabular}{|l|c|c|c|c|c|}
\hline \multirow{2}{*}{ Вариант } & \multicolumn{5}{c|}{ Наименование тяжелых металлов } \\
\cline { 2 - 6 } & $\mathrm{Zn}$ & $\mathrm{Cu}$ & $\mathrm{Pb}$ & $\mathrm{Ni}$ & $\mathrm{Cd}$ \\
\hline 1. Без ОГСВ и клиноптилолита (контроль) & 13,9 & 1,12 & 0,047 & 0,030 & 0,008 \\
\hline 2. Клиноптилолит 10 т/га & 10,0 & 0,91 & 0,020 & 0,020 & 0,006 \\
\hline 3. ОГСВ 100 т/га & 18,9 & 1,61 & 0,097 & 0,060 & 0,010 \\
\hline 4. ОГСВ 120 т/га & 22,7 & 1,94 & 0,114 & 0,075 & 0,012 \\
\hline 5. ОГСВ 140 т/га & 26,6 & 2,25 & 0,134 & 0,088 & 0,013 \\
\hline 6. ОГСВ 160 т/га & 30,3 & 2,58 & 0,158 & 0,105 & 0,016 \\
\hline 7. ОГСВ 180 т/га & 32,3 & 2,90 & 0,177 & 0,119 & 0,018 \\
\hline 8. ОГСВ 100 т/га + клиноптилолит 10 т/га & 14,7 & 1,30 & 0,065 & 0,045 & 0,008 \\
\hline 9. ОГСВ 120 т/га + клиноптилолит 10 т/га & 18,7 & 1,68 & 0,094 & 0,056 & 0,010 \\
\hline 10. ОГСВ 140 т/га + клиноптилолит 10 т/га & 22,8 & 2,01 & 0,115 & 0,068 & 0,011 \\
\hline 11. ОГСВ 160 т/га + клиноптилолит 10 т/га & 25,9 & 2,26 & 0,127 & 0,084 & 0,013 \\
\hline 12. ОГСВ 180 т/га + клиноптилолит 10 т/га & 28,6 & 2,57 & 0,146 & 0,097 & 0,016 \\
\hline ПДК & 50,0 & 10,0 & 0,200 & 0,300 & 0,030 \\
\hline
\end{tabular}

Комплексное последействие осадков городских сточных вод с цеолитсодержащей породой в меньшей степени повышало концентрацию тяжелых металлов в зерне овса по сравнению с аналогичными вариантами, где осадки городских сточных вод использовались без химического мелиоранта. Содержание цинка на фоне их комплексного последействия было ниже, чем на фоне одностороннего последействия осадков городских сточных вод на 3,74,2 мг/кг, меди - на 0,31-0,33 мг/кг, свинца на 0,031-0,032 мг/кг, никеля - на 0,0150,022 мг/кг, кадмия - на 0,020 мг/кг.

Последействие цеолитсодержащей породы снижало концентрацию цинка в зерне гороха по сравнению с контрольным вариантом в условиях 2019 года на 3,9 мг/кг, меди - на 0,20 мг/кг, свинца - на 0,028 мг/кг, никеля - на 0,011 мг/кг, кадмия - на 0,002 мг/кг (табл. 5).

Последействие осадков городских сточных вод повышало содержание цинка по отношению к контролю в зерне гороха на
4,8-18,1 мг/кг, меди - на 0,49-1,74 мг/кг, свинца - на 0,049-0,125 мг/кг, никеля - на 0,0300,088 мг/кг, кадмия - на 0,002-0,010 мг/кг.

Снижение концентрации цинка в зерне гороха на фроне комплексного последействия осадков городских сточных вод с цеолитсодержащей породой по сравнению с вариантами одностороннего последействия осадков городских сточных вод составляло 3,7-4,2 мг/кг, меди - 0,31-0,33 мг/кг, свинца - 0,029-0,031 мг/кг, никеля - 0,0140,023 мг/кг, кадмия - 0,001-0,003 мг/кг.

\section{Заключение}

Из вышеизложенного следует, что наиболее существенное влияние на урожайность овса Конкур, урожайность гороха Джекпот, сбор переваримого протеина и содержание белка оказало комплексное последействие осадков городских сточных вод с цеолитсодержащей породой.

Одностороннее последействие цеолитсодержащей породы снижало накопление тяжелых металлов в зерне овса и гороха. Последействие мелиоративных норм осад-

Таблица 5

Содержание тяжелых металлов в зерне гороха, мг/к己

\begin{tabular}{|l|c|c|c|c|c|}
\hline \multirow{2}{*}{ Вариант } & \multicolumn{4}{c|}{ Наименование тяжелых металлов } \\
\cline { 2 - 6 } & $\mathrm{Zn}$ & $\mathrm{Cu}$ & $\mathrm{Pb}$ & $\mathrm{Ni}$ & $\mathrm{Cd}$ \\
\hline 1. Без ОГСВ и клиноптилолита (контроль) & 13,8 & 1,10 & 0,046 & 0,028 & 0,007 \\
\hline 2. Клиноптилолит 10 т/га & 9,9 & 0,90 & 0,018 & 0,019 & 0,005 \\
\hline 3. ОГСВ 100 т/га & 18,6 & 1,59 & 0,095 & 0,058 & 0,009 \\
\hline 4. ОГСВ 120 т/га & 22,3 & 1,90 & 0,111 & 0,072 & 0,011 \\
\hline 5. ОГСВ 140 т/га & 26,1 & 2,21 & 0,130 & 0,086 & 0,013 \\
\hline 6. ОГСВ 160 т/га & 30,0 & 2,56 & 0,154 & 0,102 & 0,015 \\
\hline 7. ОГСВ 180 т/га & 31,9 & 2,84 & 0,171 & 0,116 & 0,017 \\
\hline 8. ОГСВ 100 т/га + клиноптилолит 10 т/га & 14,4 & 1,26 & 0,064 & 0,044 & 0,008 \\
\hline 9. ОГСВ 120 т/га + клиноптилолит 10 т/га & 18,3 & 1,66 & 0,092 & 0,054 & 0,009 \\
\hline 10. ОГСВ 140 т/га + клиноптилолит 10 т/га & 22,4 & 1,98 & 0,111 & 0,065 & 0,010 \\
\hline 11. ОГСВ 160 т/га + клиноптилолит 10 т/га & 25,5 & 2,21 & 0,124 & 0,081 & 0,012 \\
\hline 12. ОГСВ 180 т/га + клиноптилолит 10 т/га & 28,2 & 2,53 & 0,142 & 0,093 & 0,014 \\
\hline ПДК & 50,0 & 10,0 & 0,200 & 0,300 & 0,030 \\
\hline
\end{tabular}


ков городских сточных вод и их последействие в комплексе с цеолитсодержащей породой повышало концентрацию тяжелых металлов в товарной части овса и гороха. Однако, концентрация тяжелых металлов была существенно ниже ПДК.

\section{Лumepamypa}

1. Дорошкевич, С. Г. Агрохимическая эфффективность и экологическая оценка применения осадков городских сточных вод и цеолитов на аллювиальных дерновых почвах Бурятии: автореферат диссертации кандидата биологических наук / С. Г. Дорошкевич. - Улан-Удэ, 2000. - 19 с.

2. Арефьев, А. Н. Влияние осадков сточных вод и их сочетаний с цеолитом на плодородие лугово-черноземной почвы и урожайность сельскохозяйственных культур / А. Н. Арефьев // Агропромышленные технологии Центральной России. - 2017. - № 2 (4). - С. 37-45.

3. Кузнецов, А. Ю. Влияние природного цеолита и удобрений на свойства почвы и урожайность сельскохозяйственных культур / А. Ю. Кузнецов, Е. Н. Кузин // Плодородие. - 2009. - № 3. C. 12-13.

4. Нгуен, В. Б. Возможность применения природных цеолитов для повышения продуктивности и качества растений: автореферат диссертации кандидата биологических наук / В. Б. Нгуен. Москва, 1988. - 24 с.

5. Ноздрина, С. И. Экологическая эффективность применения осадка сточных вод и цеолитовых туфов в системе почва-растения (В условиях черноземных почв Орловской области): авторефрерат диссертации кандидата сельскохозяйственных наук / С. И. Ноздрин. - Орел, 2004. - 25 с.

6. Dariah, A. Application of ameliorant for improving soil quality and chili (Capsicum annum L.) productivity on degraded acidic upland / A. Dariah, N. L. Nurida // IOP Conference Series: Earth and Environmental Science. - 2019. - № 393 (1). - P. 12-41.

7. Pond, W. G. Zeo-agriculture. Use of natural zeolites in agriculture and aquaculture / W. G. Pond, F. A. Mumpton // Westview Press. - USA, 1984. - 296 p.

8. Akram, M. A. Agronomic zinc biofortification of wheat to improve accumulation, bioavailability, productivity and use efficiency / M. A. Akram, N. Depar, M. Irfan // Eurasian Journal of Soil Science. 2020. - 9 (1). - P. 75-84.

9. Singh, D. P. Agrowaste bioconversion and microbial fortification have prospects for soil health, crop productivity, and eco-enterprising / D. P. Singh, R. Prabha, S. Renu, P. K. Sahu, V. Singh // International Journal of Recycling of Organic Waste in Agriculture. - 2019. - № 8. - P. 457-472.

10. Ананьева, Ю. С. Экологическая оценка воздействия осадков сточных вод на почву по фритотестированию / Ю. С. Ананьева, А. С. Давыдов // Вестник Алтайского государственного аграрного университета. - 2009. - № 8 (58). - С. 38-40.

11. Бадмаев, А. Б. Влияние осадков сточных вод и их смеси с минеральными удобрениями на урожайность и качество картофеля / А. Б. Бадмаев, Л. Л. Убугунов, С. Г. Дорошкевич // Агро XXI. 2007. - № 1-3. - С. 31-33.

12. Агроэкологическое действие осадка сточных вод и его смесей с цеолитом на агроценозы масличных культур / Д. В. Виноградов, В. М. Василева, М. П. Макарова, Б. И. Кочуров, Е. И. Лупова // Теоретическая и прикладная экология. - 2019. - № 3. - С. 127-133.

13. Зубко, И. А. Влияние осадков сточных вод на продуктивность и качество картофеля / И. А. Зубко, М. С. Чемерис // Вестник НГАУ. - 2011. - № 1(17). - С. 32-35.

14. Чеботарев, Н. Т. Агроэкологическая оценка применения осадков сточных вод в качестве удобрений сельскохозяйственных культур / Н. Т. Чеботарев, Н. Д. Найденов, А. А. Юдин // Наука. Мысль. - 2016. - № 1-2. - С. 31-36.

15. Минеев, В. Г. Использование природных цеолитов для предотвращения загрязнения почвы и растений тяжелыми металлами / В. Г. Минеев, А. В. Кочетавкин, В. Б. Нгуен // Агрохимия. 1989. - № 8. - С. 89-95.

UDC $631.8+631.559$

DOI 10.36461/NP.2020.54.1.010

\section{CONSEQUENCE OF SEDIMENTS OF SEWAGE WATER OF THE CITY OF PENZA AND NATURAL ZEOLITES ON YIELD AND QUALITY OF PLANT PRODUCTS}

\section{A. N. Arefyev, Doctor of Agricultural Sciences, Assistant-professor; E. N. Kuzin, Doctor of Agricultural Sciences, Professor; G. V. Ilyina, Doctor of Biological Sciences, Professor}

Federal State Budgetary Educational Institution of Higher Education «Penza State Agrarian University», Russia, t. (8412) 62-83-67, e-mail: aan241075@yandex.ru

In conditions of a low level of use of mineral fertilizers in agriculture due to their high cost and the almost complete absence of organic fertilizers, the development and implementation of technological methods for using alternative sources of organic matter and nutrients in agricultural practice is an important area of modern farming. 
The objective of the research was to study the aftereffect of reclamation norms of sewage sludge in the city of Penza and their combinations with zeolite-containing rocks on the yield and quality of crop products. The studies were conducted in the first agricultural-soil region of the Penza region in grain-crop rotation in the period from 2014 to 2019. It was established that the most significant effect on the grain yield of oats and peas was exerted by increased sediments rates of urban wastewater with zeolitecontaining rock. The yield of oats against their background increased by $43.5-44.2 \%$, the productivity of peas - by $48.9-49.8 \%$. The collection of digestible protein in oat crops against their background was 487.9-490.3 kg/ha, the protein content in pea grain increased by $2.3-2.7 \%$. Sediments of urban wastewater in its pure form and in combination with zeolite-containing rock increased the concentration of heavy metals in the grain of oats and peas. However, the concentration of heavy metals was significantly lower than the maximum permissible concentration. The zeolite-containing rock reduced the influx of heavy metals into the marketable part of crop production.

Key words: urban sewage water, zeolite-containing rock, oats, peas, digestible protein, protein.

\section{References:}

1. Doroshkevich, S. G. Agrochemical efficiency and environmental assessment of the use of sediments of urban wastewater and zeolites on alluvial sod soils of Buryatia: abstract of the dissertation of the candidate of biological sciences / S. G. Doroshkevich. - Ulan-Ude, 2000. - 19 p.

2. Arefyev, A. N. The influence of sewage sediments and their combinations with zeolite on the fertility of meadow chernozem soil and crop productivity / A. N. Arefyev // Agro-industrial technology Central Russia. - 2017. - № 2 (4). - P. 37-45.

3. Kuznetsov, A. Yu. The influence of natural zeolite and fertilizers on soil properties and crop yields / A. Yu. Kuznetsov, E. N. Kuzin // Plodorodie. - 2009. - № 3. - P. 12-13.

4. Nguyen, V. B. The possibility of using natural zeolites to increase productivity and plant quality: abstract of the dissertation of the candidate of biological sciences / V. B. Nguyen. - Moscow, 1988. $24 \mathrm{p}$.

5. Nozdrina, S. I. Environmental effectiveness of the application of sewage sludge and zeolite tuffs in the soil-plant system (In the conditions of black soil in the Oryol region): abstract of the dissertation of the candidate of agricultural sciences / S. I. Nozdrin. - Oryol, 2004. - 25 p.

6. Dariah, A. Application of ameliorant for improving soil quality and chili (Capsicum annum L.) productivity on degraded acidic upland / A. Dariah, N. L. Nurida // IOP Conference Series: Earth and Environmental Science. - 2019. - № 393 (1). - P. 12-41.

7. Pond, W. G. Zeo-agriculture. Use of natural zeolites in agriculture and aquaculture / W. G. Pond, F. A. Mumpton // Westview Press. - USA, 1984. - 296 p.

8. Akram, M. A. Agronomic zinc biofortification of wheat to improve accumulation, bioavailability, productivity and use efficiency / M. A. Akram, N. Depar, M. Irfan // Eurasian Journal of Soil Science. 2020. - 9 (1). - P. 75-84.

9. Singh, D. P. Agrowaste bioconversion and microbial fortification have prospects for soil health, crop productivity, and eco-enterprising / D. P. Singh, R. Prabha, S. Renu, P. K. Sahu, V. Singh // International Journal of Recycling of Organic Waste in Agriculture. - 2019. - № 8. - P. 457-472.

10. Ananyeva, Yu. S. Ecological assessment of the impact of sewage sludge on soil by phytotesting / Yu. S. Ananyeva, A. S. Davydov // Bulletin of the Altai State Agrarian University. - 2009. - № 8 (58). P. 38-40.

11. Badmaev, A. B. The effect of sewage sludge and their mixtures with mineral fertilizers on the yield and quality of potatoes / A. B. Badmaev, L. L. Ubugunov, S. G. Doroshkevich // Agro XXI. - 2007. № 1-3. - P. 31-33.

12. Agroecological effect of sewage sediments and their mixtures with zeolite on agrocenoses of oilseeds / D. V. Vinogradov, V. M. Vasileva, M. P. Makarova, B. I. Kochurov, E. I. Lupova // Theoretical and Applied Ecology. - 2019.- № 3. - P. 127-133.

13. Zubko, I. A. The effect of sewage sediments on the productivity and quality of potatoes / I. A. Zubko, M. S. Chemeris // Bulletin of NSAU. - 2011. - № 1 (17). - P. 32-35.

14. Chebotarev, N. T. Agroecological assessment of the use of sewage sludge as fertilizers of agricultural crops / N. T. Chebotarev, N. D. Naidenov, A. A. Yudin // A science. Thought. - 2016. - № 1-2. P. 31-36.

15. Mineev, V. G. The use of natural zeolites to prevent pollution of soil and plants with heavy metals / V. G. Mineev, A. V. Kochetavkin, V. B. Nguyen // Agricultural chemistry. - 1989. - № 8. - P. 89-95. 